\title{
OVERVIEW OF IPA HU-SRB CROSS BORDER PROJECTS IN THE AGRICULTURE SECTOR IN NORTHERN PART OF SERBIA
}

\author{
Nikolina Petrović1, Krisztián Ritter ${ }^{2}$ \\ ${ }^{1} \mathrm{PhD}$ student, ${ }^{2}$ Associate professor \\ ${ }^{1}$ Hungarian University of Agriculture and Life Sciences, Doctoral School of Economy and \\ Regional Sciences \\ ${ }^{2}$ Hungarian University of Agriculture and Life Sciences, Department for Sustainable Rural \\ Development \\ E-mail: petrovicnikolina7@gmail.com¹, ritter.krisztian@uni-mate.hu²
}

\begin{abstract}
The paper is presenting an overview of six cross-border projects realized between Hungary and Serbia in the agricultural sector in the period 2010-2013. The aim of the research is to interpret projects' goals, achievements, weaknesses, and contributions in socio-economic development of the northern bordering region of Serbia. The analysis was carried out using the benchmarking method, focusing on three aspects: projects' impact on the market, social integrity, and project sustainability, with each dimension containing a set of indicators defined based on the conducted interviews with leads/beneficiaries.
\end{abstract}

Kulcsszavak: cross-border cooperation, agriculture, Hungary-Serbia, IPA, benchmarking JEL besorolás: $R 0, R 58, O 1, O 18, O 22$

LCC: HD72-88, HD2330, HT390-395

\section{Introduction}

Serbia is a developing country (as it has one of the lowest GDP in Europe), currently in the process of joining the European Union (EU) with the status of potential candidate country. Accession to the EU is a voluntary decision of one country but the decision about acceptance is made by the Member States (MS) countries. As every newly joined country has different socio-economic features that might cause regional disparities, the EU is providing financial support helping potential MS countries to synchronize policies, objectives and achieve coherent regulations to prevent potential harness of the EU as a big region itself. There were several programmes like CARDS, PHARE and IPA. The subject of this analysis is IPA (Pre - accession Assistance) which represents one of the Cohesion policy's tools that aimed to strengthen regional economic and social cohesion before joining the EU. IPA was for the first time introduced in Serbia in 2007 when the first Programming period started (2007 - 2013) with Hungary. CBC has two main Pillars: Sustainable socio - economic development and Technical Assistance implemented under one of the following four Axes: (1) Improving cross-border water management and risk poverty system; (2) Decreasing bottleneck of cross border traffic; (3) Encouraging tourism and cultural heritage cooperation; (4) Enhancing SMEs' economic competitiveness through innovation-driven development (IPA HU-SRB Project Catalog, 2016).

Before giving a projects' overview presented in this research paper it is important to understand what a cross-border region means and how it is defined. There are several definitions but one of the most common is defining borders as physical lines which make clear borderline between two or more countries. In terms of the physical appearance of border areas, they can be defined as an edge on the national space interfacing neighboring countries (Grundy, 1997). Sousa evaluates cross-border cooperation in the EU purchasing definition which does not define cross- 
border regions as ,territory of two or more neighboring countries divided by a fixed jurisdictional line that separates them" (Sousa, 2013: pp. 2-3.). He defines regions as areas of social, cultural, economic, and political exchange and where many transaction activities take place. Sousa provides a simpler definition stating borders as a ,set of sociocultural practices, symbols, institutions, and networks “. In the EU, borders are open - meaning not only free movement of people, goods, services, capital, and transactions, but also regional co-operation which has been gaining more significance after the Second World War.

Sousa (2013: 5. p.) although states that "co-operation is a voluntary process in which states or sub-national territorial units act together in order of getting common benefits". According to the author, co-operation in terms of operational function can be any activity between public and/or private institutions in the border regions brought together by geographic, socioeconomic, cultural, or political factors with the common aim of maintaining a good neighborhood relation, and mutually finding solutions for overcoming common problems.

Enhancing regional co-operation is not an easy task. Based on Schiff and Winters (2002), some of the factors can slow down or break the co-operations - such as political tensions, lack of trust, the misbalanced share of costs and allocation of benefits, high costs of administrative coordination between countries involved in co-operation process, regional agreements - are more difficult to establish, involve effort and time, with the language barrier making the process even more difficult. Cross-border obstacles have been divided into four groups by the cited authors: 1. Poor economic performance, higher unemployment rate, marginalized agriculture production, lack of business services, distortion of trade; 2. Lack of social services, lower welfare systems, lower income per capita; 3 . Poor infrastructure and communication networks; 4. Poor natural resources endowments. The obstacles emerged due to the unfavorable territorial position of cross-border regions, peripheral location, isolated position, and distance from urban centers. Some of the authors analyzed the impact of cross-border program on the economic, social, and environmental dimensions of sustainable development.

Cappelo et al. (2017) state that border regions have similar features and resources as other regions. They usually interact through $\mathrm{CBC}$ projects as they find similar interests and have alike features characterized by sharing the same history and culture. Common characteristics are employment, industry, human capital, innovation. A segment in which border regions prevail is the diversity of cultural events which improve the quality of life. Negative features are low accessibility, population density, the internal trust which can be explained by the historical and geographical trust. As CBC regions have peripheral status according to AEBR (Association of European Border Regions), they are structurally weak areas with undeveloped transport structure - roads and railways, employment, culture, and demographic density.

The northern part of Serbia can be described similarly, as per Cvejic (2010), some of the main issues are: unfavorable demographic structure, "brain drain", undeveloped communal infrastructure, weak business infrastructure, financial poverty, and settlement deprivation. According to Molnar (2013), greater territorial disparities and negative effects are more visible in the larger extent in smaller territorial units e.g. settlements rather than bigger cities. The Program Development Plan AP Vojvodina 2014 - 2020 (2013) shows that level of development for 13 municipalities out of the total number of 45 municipalities is under average, with 3 municipalities targeted as underdeveloped and the others reaching the stage of average development.

In the Vojvodina region, around $43 \%$ (approx. 796.500) of the total population is settled in rural areas (Hungary - Serbia IPA Cross - border Co-operation Program, 2015), where 
agriculture represents the main economic activity characterized by small-scaled households (up to $5 \mathrm{ha}$ ), with other sectors active in lower extent, such as manufacturing, trading, and services. According to Pejanovic and Njegovan (2011), almost 400 villages in Vojvodina have disappeared because of the rapid demographic abandonment. Vojvodina covers around 1.65 million ha of arable land mainly in possession by village estates, farmers, or farming cooperatives. Around $13 \%$ of the total population is engaged in the agriculture sector. According to the Statistical Office of the Republic of Serbia, the average number of people who are engaged actively in the agriculture sector are employees at legal entities, persons individually running businesses, unincorporated enterprises, and the number of employees in the agriculture sector in 2017 in the Vojvodina region was 18.852 while the number of employed people was 132.600 .

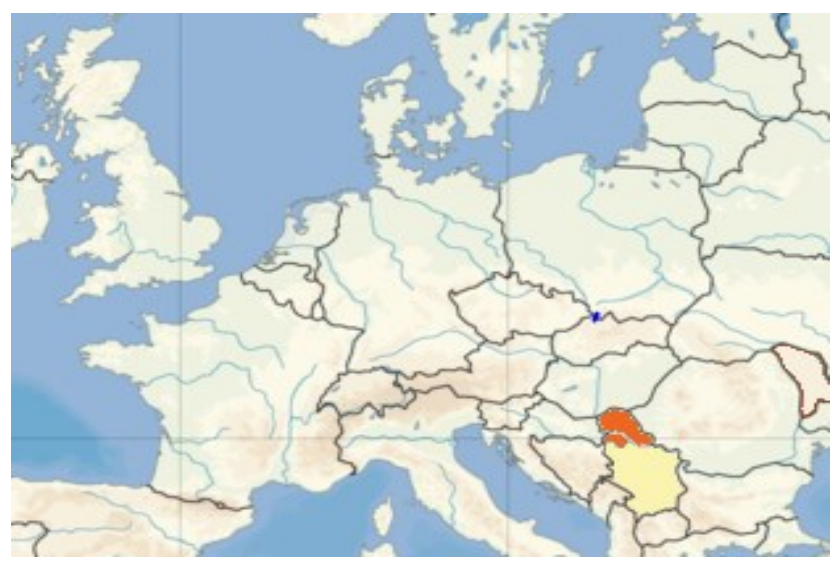

\section{Figure 1: Location of Serbia (Vojvodina Region) in Europe}

Source: commons.wikimedia.com, 2021

Some of the reasons for that unfavorable situation regarding socio-economic conditions is, as per Devetakovic (2002), Miljanovic et al. (2009), state incapacity to manage regional development and its policy maintenance in an adequate manner. Serbia was not prepared to answer the challenges which industrialization, urbanizaton, and deagrarization (Devetakovic, 2002) brought in the 1990s and early 2000s, which consequences can be felt even nowadays. This is just the brief view of the challenges that the region is facing these days, but by taking part in the EU programmes there is a belief that Serbia can follow the right track towards better and more sustainable development.

\section{Materials and methods}

The main aim of the research is to evaluate the Cross-border projects between Hungary and Serbia run during the first Programming period. The analysed projects are in the time frame from 2010 to 2013 (as the first part of the programming period was focused mainly on the formulation of the development plans and infrastructure, with projects focused on the entrepreneurial sector starting from 2010) presenting their impact on the development of the agriculture sector. The subject of the analysis are projects which belong to the Axes 4: Enhancing SMEs' economic competitiveness through innovation-driven development. Axis 4 is enforcing the growth capabilities and employment potential of SMEs through the development and adaptation of new technologies, processes, products, or services in the agriculture sector.

The research is based on the evaluation of primary and secondary data. Primary data are collected by conducting face-to-face and phone interviews with Leader/Project Partners (project coordinators) in Serbia in 2017 in order to collect data about the projects and in 2020 
to confirm visibility and sustainability of the achieved results. The Secondary data were collected from the internal reports, brochures, and HU-SRB programme and projects' websites. In total six projects were evaluated. The main method used for evaluation is Benchmarking methodology measuring socio-economic impact of the project activities with the focus on its sustainability. For this purpose, a set of indicators (criteria) were established by the authors grouped into 3 categories: Project impact on the market, Social Integration and Project's sustainability (see Table 1).

Table 1: Project's Criteria (Benches)

\begin{tabular}{|c|c|c|}
\hline \multicolumn{3}{|c|}{ I - Project Impact on the market } \\
\hline Criteria & Criteria Description & Data Source \\
\hline $\begin{array}{l}\text { 1. Number of entities } \\
\text { benefiting from the project } \\
\text { (expanding business) }\end{array}$ & $\begin{array}{l}\text { Number of entities directly benefiting from the project } \\
\text { (registered active agricultural producers, SMEs, or individual } \\
\text { farmers) }\end{array}$ & $\begin{array}{l}\text { Interview, web } \\
\text { database }\end{array}$ \\
\hline $\begin{array}{l}\text { 2. Categories that } \\
\text { participants belong to }\end{array}$ & $\begin{array}{l}\text { Diverse of participants categories benefiting from the project } \\
\text { (Individual farmers, Agricultural Associations, SMEs (food } \\
\text { processing, food trade), companies, R\&D }\end{array}$ & $\begin{array}{lr}\text { Interview, } & \text { project } \\
\text { websites, } & \text { web } \\
\text { database } & \\
\end{array}$ \\
\hline $\begin{array}{l}\text { 3. Enhancing the } \\
\text { competitiveness of farm } \\
\text { households/SMEs }\end{array}$ & $\begin{array}{l}\text { Improving competitiveness introducing innovations in terms } \\
\text { of improvement of quality of the products and/or promotion } \\
\text { (during the production of raw agricultural products or } \\
\text { processed) }\end{array}$ & $\begin{array}{l}\text { Interview, project } \\
\text { website, secondary } \\
\text { data (reports) }\end{array}$ \\
\hline $\begin{array}{ll}4 . & \text { E-Business } \\
\text { infrastructure } & \end{array}$ & $\begin{array}{l}\text { Level of the business infrastructure (e-business base) } \\
\text { improvement and its usage }\end{array}$ & Project web sites \\
\hline $\begin{array}{l}\text { 5. Supporting the education } \\
\text { of the participants through } \\
\text { workshops, training, } \\
\text { vocational schools, etc. }\end{array}$ & $\begin{array}{l}\text { Supporting the education of the participants through } \\
\text { workshops, training, vocational schools etc. }\end{array}$ & $\begin{array}{l}\text { Interview, } \\
\text { database }\end{array}$ \\
\hline \multicolumn{3}{|c|}{ II - Social Integration } \\
\hline Criteria & Criteria Description & Data Source \\
\hline $\begin{array}{l}\text { 1. Community } \begin{array}{l}\text { building } \\
\text { (through } \\
\text { conferences) }\end{array} \\
\end{array}$ & $\begin{array}{l}\text { Number of activities that support community building } \\
\text { exchanging participants in the bordering region through } \\
\text { activities like fairs, conferences, study visits. }\end{array}$ & Interview \\
\hline $\begin{array}{l}\text { 2. Region covered by the } \\
\text { project }\end{array}$ & $\begin{array}{l}\text { Number of municipalities involved in the project and location } \\
\text { of municipalities in the NUTS II bordering region. }\end{array}$ & $\begin{array}{l}\text { Project } \\
\text { database, } \\
\text { websites }\end{array}$ \\
\hline $\begin{array}{l}\text { 3. Involved Project partners } \\
\text { and stakeholders }\end{array}$ & $\begin{array}{l}\text { Number of projects that have been realized after the } \\
\text { finalization of the examined projects. }\end{array}$ & $\begin{array}{l}\text { Interview, project } \\
\text { websites }\end{array}$ \\
\hline $\begin{array}{l}\text { 4. Inclusion of } \\
\text { women/young } \\
\text { people/farmers }\end{array}$ & $\begin{array}{l}\text { Number of involved individual farmer producers gaining } \\
\text { lower income/women entrepreneurs/ }\end{array}$ & $\begin{array}{l}\text { Interview, } \begin{array}{l}\text { web } \\
\text { database, project's } \\
\text { websites }\end{array} \\
\end{array}$ \\
\hline \multicolumn{3}{|c|}{ III - Project Sustainability } \\
\hline Criteria & Criteria Description & Data Source \\
\hline $\begin{array}{l}\text { 1. Cooperation between } \\
\text { project participants and } \\
\text { local stakeholders (number } \\
\text { of engaged partners and } \\
\text { intensity of partnerships) }\end{array}$ & $\begin{array}{l}\text { Number of activities that have been carried out by the project } \\
\text { partners/local stakeholders after the finalization of the } \\
\text { examined project. }\end{array}$ & $\begin{array}{l}\text { Interview, project's } \\
\text { web sites, Project } \\
\text { Partners'websites }\end{array}$ \\
\hline $\begin{array}{l}\text { 2. Interconnection between } \\
\text { projects }\end{array}$ & $\begin{array}{l}\text { Number of projects that have been carried out before the } \\
\text { examined projects and their interconnection. }\end{array}$ & $\begin{array}{l}\text { Interview, project's } \\
\text { websites, Partner's } \\
\text { websites }\end{array}$ \\
\hline $\begin{array}{l}\text { 3. Budgetary and } \\
\text { institutional support }\end{array}$ & $\begin{array}{l}\text { Covered costs, participation of the project partners and local } \\
\text { stakeholders }\end{array}$ & $\begin{array}{l}\text { Project database, } \\
\text { interview, secondary } \\
\text { data (reports), } \\
\text { project's website. }\end{array}$ \\
\hline
\end{tabular}

Source: Authors' edition, 2021 


\section{Results and discussion}

As it was mentioned above, the analysis includes six projects in total. The analyzed projects were mainly focused on building the co-operation and capability of farmers to gain additional income through educational workshops, building databases for online trading, building up cluster cooperation, innovative way of breeding, and crop production. The projects' topic must be in line with the cohesion problem, and agriculture is one of the topics that seek attention in both countries. The programing period lasted for one year. In the next section of the paper, the comparison between projects' performance will be presented using the Benchmarking method. Projects are going to be compared by each dimension according to the previously defined criteria. In Table 5, the scores that each project achieved for each criterion and dimension are presented. Scoring was conducted on a scale from 1 - (the lowest achievement/performance) to 5 - (the highest achievement/performance). Projects which were subject of the analysis are the following:

1. Project: "New farming models in backyards as possible solutions for generating additional income and self-employment in the rural cross-border area" (code FARMADDIN/project no. HUSRB/1203/213/122), launched in 2013. The project's aim was to provide possible solutions for generating additional income and selfemployment in the rural cross-border area to deliver knowledge to the agricultural producers and SMEs due to improving the production of vegetables in the open field and greenhouses at their households. The project involved 30 participants, individual farmers, and representatives from three Producer Unions and representatives from food processing sector. The main activities conducted during the project realization were conducting a study about vegetable production in the open field and greenhouses which is transferred to the Guideline available online and as physical copy, organized workshops, and seminars, as well as updating e-platform for knowledge transfer.

2. Project: "Joint farm diversification strategy in the Hungarian - Serbian borderline" (code RURALNET - HU/ project no. HUSRB/1203/213/085) released in 2013 - 2014. The project's aim was diversification strategy in the Hungarian - Serbian borderline, including elaborated study visits which presented the base for business plan creation and picturing example how the agriculture production can be transformed to processing and tools for gaining additional income. The project was about sharing the knowledge and good practice through seminars and practices. The project involved 50 people from different municipalities.

3. Project "Cluster Building by Cooperation in the Agro-Food sector Project acronym: CBC Agro - Food" (code CBC Agro - Food/project no. HUSRB/1002/211/101) was launched in the year of $2012-2013$. Project aimed to create cluster-based cooperation between agri-food producers in Hungary and Serbia, introducing clusters and creating business cooperation between agricultural producers and agri-food companies.

4. Project "Joint SMEs Co-operation for Strengthening Export Capability" (code JCoSEC/project no. HUSRB/1002/213/175) was carried out in the year of 2012 2013. The project's aim was to increase the synergy and cooperation between SMEs in bordering regions, increasing the number of cross-border business contacts between enterprises and their cooperation for strengthening export capabilities on the third markets, and strengthening joint ventures.

5. Project "Business Linkages Among Women Living in Rural Areas" (code Business Women/project no. HUSRB/1203/211/228), started in 2013 and ended in 2014. The project aimed to support women living in rural areas to start their own businesses. Project activities conducted during the project were research study about the position of the businesswomen in the rural area, creating web portal, consulting sessions about 
start-ups, training on managing the business, and promo activities to increase the visibility of the group.

6. Project "Enhancing economic cooperation in the field of integrated agricultural supply of goods along the Serbian - Hungarian border" (code ECO - COOP/project no. HUSRB/0901/211/159) was realized in 2010 - 2011. The project's goal was enhancing economic cooperation in the field of integrated agricultural supply of goods along the Serbian - Hungarian border with the aim to enhance the integrated agricultural supply of goods and agro-trade potential of the Subotica - Szeged border economic region in the interest of increasing economic the competitiveness of the region.

As per the presented results in Table 2, it can be concluded the best performance is achieved by the project "Business Linkages Among Women Living in Rural Areas" which leads with high scores according to all sets of indicators.

Table 2: Scores by each dimension/criteria per project

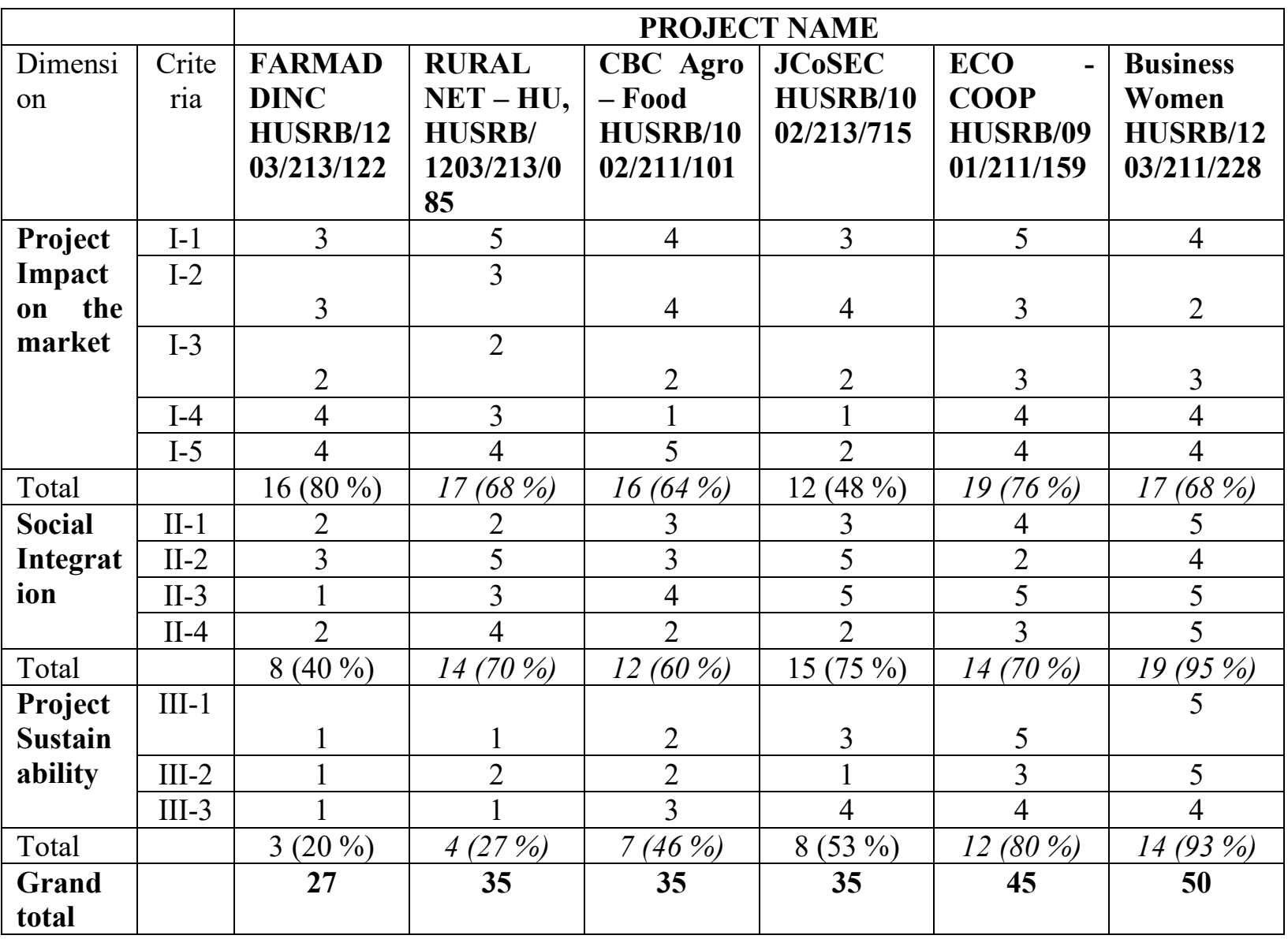

Source: Authors' evaluation and edition, 2021

All three dimensions showed positive results while Social Integration and Project Sustainability, have significantly higher scores comparing to the other projects. As one of the main objectives of the IPA programme is strengthening co-operation between partners on the local level this project fulfilled this criterion, as women in rural areas were empowered to create networks, as per the confirmation of the interviewed project partners. The project succeeded in bringing women entrepreneurs together and create strong co-operation. Moreover, they managed to extend the project duration for one additional year without IPA Programme. In the practice, the extension of the projects is not common as once the project is finalized and there 
is no more funding coming from the EU side, most of the project activities would end. But this project has proven the opposite. Some of the possible reasons might be the recognized importance of the networking established between stakeholders and women in rural areas. With the common forces and support from the local stakeholders', the activities had been organized further. The network of the businesswomen still can be found but in much lower extent. The other positive fact about the project is fulfilment of the IPA specific objectives which is: "enforcing the growth capabilities and employment potential of SMEs through the development and adaptation of new technologies, processes, products, or services" (http://www.interreg-ipahusrb.com/). One of the advantages of the project is the conducted research about the needs of businesswomen in rural areas as this topic does not draw much attention in Serbia. On the additional note, inviting research and innovation centres to advise on how products/services could be improved would have added value to the project. The disadvantage of this project is lower impact on the local/regional market and diversity. The project was focused only on the SMEs and home-made activities in the agriculture sector without involving other entities like trade SMEs, entrepreneurs from the service sector, etc. Agriculture plays the most important economic activity but despite this fact it is not the only existing sector in the northern part of Serbia. As IPA programme is not specifying what business sector should be supported it is up to the local and regional stakeholders to decide; still emphasizing only one sector is not advisable.

The next project which performed well is "Enhancing economic cooperation in the field of integrated agricultural supply of goods along the Serbian - Hungarian border", scoring 75\% in total. The Project Impact on the Market is higher compared to the other projects in terms of food supply chain and creating the connection between supply and demand in cross-border region connecting agricultural producers, trade SMEs, as well as supporting online marketing are in the centre of attention in this project. The project had a high impact on the market promotion and strengthening distribution channels. This project managed to achieve an active, updated, and functional web platform. Online customers could easily check demand and find all necessary information about sales and goods. This is very favourable as online trade of agrifood products is not much popular in Serbia and presents an innovative way of reaching out to the market and consumers, as in some areas traditional way of trading is still present due to lack of the IT skills and knowledge.

When it comes to sustainability, a strong relation between project partners and stakeholders is important as well. However, it is noted in the case when project partners/stakeholders have known each other and had co-operation before, they did not have major difficulties in the project realization and would keep the co-operation in the future. This project has proved this, as the web market platform still exists, though it should have been upgraded and extended by including a wider range of producers.

Three projects, "Joint SMEs Co-operation for Strengthening Export Capability", "Cluster Building by Cooperation in the Agro-Food sector" and "Joint farm diversification strategy in the Hungarian - Serbian borderline" have the same performance achievement of $58 \%$.

Project Impact on the Market in the case of two projects "Cluster Building by Cooperation in the Agro-Food sector" and "Joint farm diversification strategy in the Hungarian - Serbian borderline" is just above the average while in the case of the project "Joint SMEs Co-operation for Strengthening Export Capability" is below the accepted limit and it is marked as nonsatisfactory, The weakest points in all three cases were cooperation between project participants and local stakeholders as per the interviewees. 
The main objective of the project "Joint SMEs Co-operation for Strengthening Export Capability" was to increase the synergy and cooperation between SMEs in border areas, increase the number of business contacts between enterprises, and their cooperation for strengthening export capabilities on the markets. One of the main activities was introducing Serbian SMEs to the Hungarian market. Unfortunately, the project did not reach objectives fully as defined. Activities were much more focused on increasing awareness among public institutions to support cooperation between SMEs in the cross-border region which is important, but there is a long and slow road toward it, as it requires well-constructed measures and tailored solutions, as well as active participation of the legal authorities from both countries. The project was not focused on providing activities where SME representatives would have had the opportunity to meet each other's face to face and work on strengthening the future trade cooperation, neither guidance on how the international business co-operation works. According to the project coordinator, only four (out of sixty) SMEs from Serbia succeeded to make the cooperation with the Hungarian trade company. Once the project was finished the SMEs were not getting any further assistance and guidance. Establishing an organization or giving the role to some of the existing institutions e.g., the Chamber of commerce in Serbia to assist and support SMEs in the border area in Serbia could have had more fruitful results in the field of international business co-operation. There are real examples where co-operation between SMEs in the cross-border region on both sides was beneficial, like in the cross-border region in the West Ukraine (Isakova et. al., 2012), between the Czech Republic and Poland (see Kurowska - Pysz, 2016), or between Macedonia and Greece where quality control of the exported goods in an international and export system where regulations are bit more complex was simplified what presented a big step for Macedonia as a non-EU country (Smallbone et.al, 2009).

Although the third dimension Project Sustainability is marked as dissatisfactory, the performance is $53 \%$, and it is very close to crossing the line of acceptance. The reason why this dimension achieved a low score is due to the lack of co-operation between project partners and stakeholders. The project participants did not have any relation in the past but neither had they succeeded to establish and maintain business co-operation. As per the interviews with the project lead, all partners worked in a high extent individually and desynchronized. This is not the way how business co-operation should be carried out, especially not when we talk about international export, as both sides should be involved equally and at the same organizational level.

It is hard to motivate SMEs in the Serbian side to take part in the international export as there are many regulations which must be taken into consideration: different tax systems, different currencies, customs control, etc. At this point involving institutions and local leaders to provide adequate support to the SMEs in order to overcome legislative barriers is highly needed.

The next project which had achieved acceptable performance is "Cluster Building by Cooperation in the Agri-Food sector" which scored only 35 points in total (out of 60). The dimension Project Sustainability is below the average, and the reason is weak networking between project partners and stakeholders. Partners did not have any cooperation in the past. The other negative feature is the low budget. In the opinion of one of the interviewees, they were underpaid. Other shared remarks are insufficient project management skills among project coordinators as the cause of the additional pressure on the other project members. The project scored well in the Social Integration dimension, as the main participants were farmers who are actively engaged in the farming and are economically stable. Although the performance was good, the chance should have been given to the participants coming from less affluent economic background. The participants were not diversified, as diversification is one of the objectives of the IPA Programme. One of the main goals of the project was sharing the knowledge and good 
practice from Hungary about clusters, and after the project was finalized, participants were supposed to network and organize clusters by themselves, considering that participants had the skills at leading the business, however, this did not happen. The exact reason is unknown, but in the end of the last century, many of the public agricultural co-operatives were crushed. Nowadays, in the mind of the farmers there are barriers when it comes to the joined co-operation and establishment of the membership with some of the agricultural organizations as they are afraid of investing in it and losing capital as they had unpleasant experiences in the past. Project activities should have been designed in a better way, and in our opinion, the project coordinators had lack of experience when it comes to the topic clusters, what factors influence their establishment and what environment needs to be created in launching them.

The dimension Internal Project Impact on the market is evaluated as satisfactory meeting the average of the whole project. In general, activities were organized in a good manner, with many face-to-face meetings that provided the chance for the farmers to create direct connections, and participants visiting clusters in both countries through organized study visits. Anyhow, after the finalization of the project direct connection between clusters and potential founders in Serbia did not happen. But still, there was the initiation of co-operation with one of the clusters which were not taking part in this program. The assumption is that participants were motivated to create cooperation with clusters but not particularly with the ones from the project, which is still fine as each entity has different business motives.

The last project evaluated as positive is "Joint farm diversification strategy in the HungarianSerbian borderline”. The project achieved good performance in two dimensions: Project Internal Impact on the Market and Social Integration, while the Project Sustainability failed. The Project Impact on the Market and Social Integration are above the average performance.

The strong point of the Project Impact on the Market is that the project focused on strengthening the soft skills of the participants through many activities such as workshops, study research, study visits, presentation of the good practices, and knowledge transfer. The project was focused only on the future start-up's founders. One activity according to the project coordinator that should have been achieved is legalizing traditional home-made products and providing permission to local producers to sell their products at the local markets. In order to officially enter the food market, agri-food producers need to obtain certain quality certifications which require investments that most of those engaged in the agriculture sector cannot afford. On the other hand, as confirmed by the interviewee, providing support to the locals' producers in the process of business registration and raising start-up would help them to become more visible and recognizable in the market. Here as well entrepreneurs face one of the biggest obstacles high fees and taxes that local producers cannot afford with the low income. But in Serbia, this is a very complex process which should be carried out by local authorities as well, and the government should allocate the certain budget for those activities, support of the start-ups in the agriculture sector. Although there is no agriculture advisory service that could guide farmers on how to establish the business, usually they are left on their own. This project tried to provide the solution but unfortunately, it was not achieved according to the words of the project coordinator, and a certain level of dissatisfaction was present.

The last project and unfortunately the project which had the lowest performance with only 27 points out of 60 is "New farming models in backyards as possible solutions for generating additional income and self-employment in the rural cross-border area". The project achieved positive performance thanks to the dimension Project Internal Impact on the Market which got $64 \%$ but unfortunately, the performance of other dimensions, Social Integration and Project Sustainability, are below the accepted level, especially the Project Sustainability. 
The project Sustainability is evaluated as dissatisfactory as the partnership between the project and leader partner was very weak, they worked pretty much independently as two individual teams each in their own country. Based on the interviewee, the business communication and cooperation were very weak, the lead partner was unsatisfied with the cooperation in all and was not planning to renew it in the future. Budgetary and Institutional support was very poor. The Lead partner involved a very low number of stakeholders and the budget was just enough to cover basic costs. In the project coordinator's opinion, they did not have enough experience in project management and budgeting. On the other hand, the project coordinator did not have planned participants' profile, although they had difficulties with finding enough participants. It could have been seen that they were focused rather on carrying out the project activities while in that sense they lost focus on achieving project results. The other example is also project "Joint farm diversification strategy in the Hungarian - Serbian borderline" where project coordinators needed to cut down some of the activities due to overcoming the gaps during project realization which led to the delivery of the poor results. Although, as per the interviewee, neither higher future networking between participants was achieved nor co-operation between project's leaders and partners.

As it can be seen, the relations between project partner's matter. If the relation is stronger it could lead to the extension of the projects, and better sustainability. Project leaders should carefully choose their project partners to avoid the situation of the independent work rather than dependent which is in line of the IPA Programme. Some modifications regarding the programme itself are needed, like measuring the competence of the project leaders, beneficiaries, and partners, and having a database of project partners. Project coordinators are providing reports to the IPA HU-SRB but seem this is more administrative part rather than quality point control.

\section{Conclusions}

According to the examined projects run under IPA CBC 2007 - 2013 it is concluded that not all the Programme objectives have been fulfilled but there are still some positive results. In general project activities were mainly focused on supporting networking between two countries in the business sector mainly in agriculture, introducing new production processes, improvements in distribution and market. During the evaluation, some of the problems were recorded and local and regional authorities should have found a way how to overcome them together with IPA HU-SRB. The first remark is the presence of a low level of cooperation between stakeholders, project partners, and the project's targeted group (participants). Some of the main barriers were insufficient project management skills, low budget, language barrier, low level of predicting and response to the risks, insufficient background about the project topic and/or participants, and lack of motivation. Those difficulties are something that prevents project sustainability and further co-cooperation. In most cases, project activities do not last for a long time after the project finalization. The sustainability of the project activities should have been improved significantly to extend their impact in the long term. Some of the answers to these problems could be establishments of the points (hubs) that would work in the line with IPA HU-SRB and help project co-ordinators to launch the projects in the most efficient way and educate local actors on how to absorb project activities, valorize and utilize them in the best possible way. Such hubs could help project coordinators to strengthen their skills, match the right project partners, strengthen their partnership relations. In the future, the project coordinator should screen participants' profiles and target them better. They should focus as well on the people who have leadership skills and could raise initiatives for action and improvement of socio-economic development in their own settlements. Raising awareness 
about co-operation in the cross-border region and its opportunities among local stakeholders, citizens and business entities is of high importance too.

Last but not least, a much deeper evaluation regarding projects' impact on development is needed, as well as the creation of the valuable set of indicators that currently does not exist under the IPA (Interreg) Programme is something that deserves much more attention in the future.

\section{References}

1. Capello, R. - Caragliu, A. - Fratei, U. (2017): Measuring Border Effects in European Cross-border regions. Regional Studies vol. 52 (7). 986 - 996 p., http://doi.org/10.1080/00343404.2017.1364843.

2. Cvejić, S. - Babovic, M. - Petrovic, M. - Bogdanov, N. - Vukovic, O. (2010): Socijalna isključenost u ruralnim oblastima Srbije. UNDP Srbija, SeCons, Belgrade, Serbia,

3. ISBN: 978-86-7728-137-3.

4. DP - Development Program AP Vojvodina 2014 - 2020 (2013): Republic of Serbia, AP Vojvodina, Provincial Government, Serbia (Retrieved from: http://programrazvoja.vojvodina.gov.rs/ - January 2021).

5. Devetakovic, S. (2002): Razvoj i perspective regionalne politike evropske unije. Ekonomski anali 43 (155) 129 - 142. p., http://doi.org/10.2298/EKA0205129D.

6. Grundy, W. C. (1997): Eurasia: World Boundaries, vol. 3. Routledge, New York.

7. ISBN 0-415-08834-8.

8. Hungary Serbia IPA Cross Border Cooperation Programme (2015): Interreg - IPA CBC Hungary - Serbia Programme, Draft (Retrieved from: https://ec.europa.eu/transparency/regdoc/rep/3/2015/EN/3-2015-9488-EN-F1-1ANNEX-1.PDF - December 2020)

9. Isakova, N. - Gryga, V. - Krasovska, O. (2012): Cross border co-operation and innovation in SMEs in Western Ukraine. 135-156. p. In: Smallbone, D. - Welter, F. Xheneti, M. (Eds): Cross-Border Entrepreneurship and Economic Development in Europe's Border Regions. Edward Elgar Publishing, Cheltenham http://doi.org/10.4337/9781781952160.00017.

10. Kurowska, Z. - Pysz, J. (2016): Opportunities for Cross Border Entrepreneurship Development in the Cluster Model Exemplified by the Polish - Czech Border Region. 1-21. p. In: Jablonsky, A. (Ed.): Sustainable Business Model. MDPI, Basel. ISBN: 978-3-03897-561-8.

11. Mihailovic, B. - Cvijanovic, D. - Parausic, V. (2013): Analiza performansi primarne poljoprivredne proizvodnje i prehrambene industrije Srbije. Agroknowledge vol.14. (1) 77-85. p., http://doi.org/10.7251/AGRSR1301077M.

12. Milanovic, D. - Miletic, R. - Djordjevic, J. (2010): Regional inequality in Serbia as a development problem. Acta geographica Slovenica, vol. 50. (2) 253-275. p., http://doi.org/10.3986/AGS50204.

13. Molnar, D. (2013): Dinamika i struktura regionalnih dispariteta u Srbiji tokm perioda 2001 - 2010 Ekonommski vidic, vol. 28. (2-3) 175-188. p., ISBN: 978-3-03897-5618.

14. Pejanović, R. - Njegovan, Z. (2011): Principi ekonomije i agrarna politika, monografija, Univerzitet u Novom Sadu, Poljoprivredni Fakultet, Departman za ekonomiku poljoprivrede i sociologiju sela, Novi Sad. ISBN: 978 - 7520 - 212 - 7.

15. Project Catalog, Interreg IPA CBC Hungary - Serbia (2016), Hungary Serbia IPA Cross-border Cooperation Programme, Joint Techical Secretariat, Budapest, Hungary. ISBN: 978 - 963 - 12 - 2866 - 3. 
16. Schiff, M. - Winters, A.L. (2002): Regional Cooperation, and the Role of International Organizations and Regional Integration. Policy Research working paper. The World Bank Development Research Group Trade. DOI:10.1596/1813-9450-2872.

17. Sousa, D.L. (2013): Understanding European Cross-border Cooperation: A Framework for Analysis. Journal of European Integration vol. 35. (6) 1-19. p., http://doi.org/10.1080/07036337.2012.711827.

18. Smallbone, D. - Xhenti, M. - Welter, F. (2009): Enterprise Cross Border Co-operation as a Form of International Entrepreneurship. 1-20. p. In: Rent XXIII Conference "Entrepreneurial Growth of the Firm", Budapest, Hungary. ISSN: 2219 - 5572.

19. Statistical Yearbook of Republic of Serbia (2018). Statistical Office of Republic of Serbia, Belgrade, Serbia. 